\title{
Evaluation of Poultry Litter Traditional Composting Process
}

\author{
Carlos Eduardo Sanchuki, Carlos Ricardo Soccol, Júlio Cesar de Carvalho, Vanete \\ Thomaz Soccol, Camila do Nascimento and Adenise Lorenci Woiciechowski* \\ Departamento de Engenharia Química; Divisão de Engenharia de Bioprocessos e Biotecnologia; Universidade \\ Federal do Paraná; Curitiba - PR - Brasil
}

\begin{abstract}
The objective of this work was to study the poultry litter composting and evaluate the physico-chemical and microbiological transformations as a time-function. At the end of composting, an increase of humification matter, a decrease of microbial diversity and the elimination of pathogens were observed. Results showed that poultry litter was liable of composting, without any nutritional complementation or inoculation and the process occurred similarly to other kind of organic residues.
\end{abstract}

Key words: Poultry litter, composting, organic residues, thermophilic phase

\section{INTRODUCTION}

Agroindustrial residues frequently represent a volume bigger than the products themselves. Poultry litter stands among the industrial residues, and is composed by faeces, feather, remains of the feed and a support matrix which can vary according to the country and region, such as sawdust, shavings, peanut shell, rice husk and others materials. According to Associação Brasileira de Exportadores e Produtores de Frango de Corte (2009), in 2008 Brazil was the largest exporter of broiler, generating around 11 billion $\mathrm{Kg}$ of poultry litter (Aires, 2009).

Poultry litter was largely used on pasture fertilization and animal feeding until 2001, when its use was forbidden by the Normative Instruction n. 15 from the Ministério da Agricultura, Pecuária e Abastecimento (Brazil, 2001). Therefore, other alternatives for use and arrangement of this material are necessary. According to Kozen (2003), poultry litter offers great potential as fertilizer for the vegetation fertilization, Gobbi et al., (2000) used it in the culture of Zea mays as a supplement of macro-nutrients. There are several other residues which can be used as fertlizers to improve the fertility of the soil; for example sewage sludge is used to increase the amount of nutrients in the soil (Faveretto et al., 2007; Fonseca et al., 1997). However, it is necessary to ensure that no pathogens are released in the environment through the application of such residues. One of the methods to ensure this protection and improve the quality of the fertilizer is composting, which improves the quality and availability of the nutrients in the soil and eliminates pathogenic organisms. The compost can be characterized as stabilized and pleasant odor

*Author for correspondence: adenise@ufpr.br 
organic matter, free of pathogens. It is considered an excellent organic fertilizer due to the presence of minerals and húmus. The organic matter, added to soil as organic fertilizer, improves the physicochemical and biological soil properties (Kiehl, 2002).

The important chemical properties in the organic fertilizers and soil conditioners are organic matter content, moisture, $\mathrm{pH}$, cation exchange capacity (CEC) and soluble salts (Matos, 2006). To assure the compost sanitary security, it is necessary that the thermophilic phase lasts for a reasonable period so that most of the pathogenic microorganisms do not survive (Brazil, 2009).

The objective of this study was to compost poultry litter, "in natura" without any thermal or chemical pré-treatment, nutritional correction or inoculation.

\section{MATERIALS AND METHODS}

\section{Poultry litter}

The litter was collected from a poultry grange located in the city of Mandirituba/PR. Third brood poultry litter was gathered from several spots of the hangar.

\section{Construction of bioreactors for composting evaluation}

In order to simulate the composting stack, expanded polystyrene bioreactors were made, maintaining the temperature during the thermophilic phase of the process. The aeration was done through forced air injection from the bottom of the bioreactor (Fig. 1).

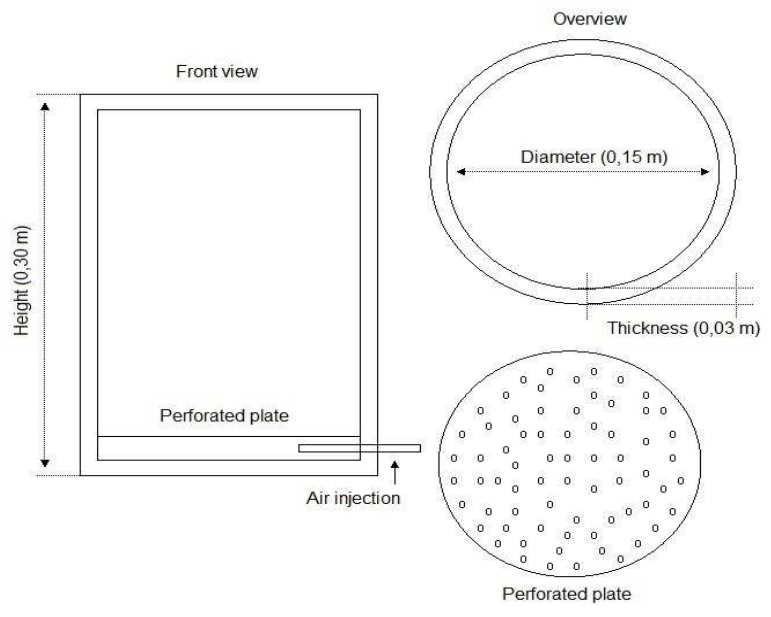

Figure 1 - Schematic drawing of the bioreactor used in the study.

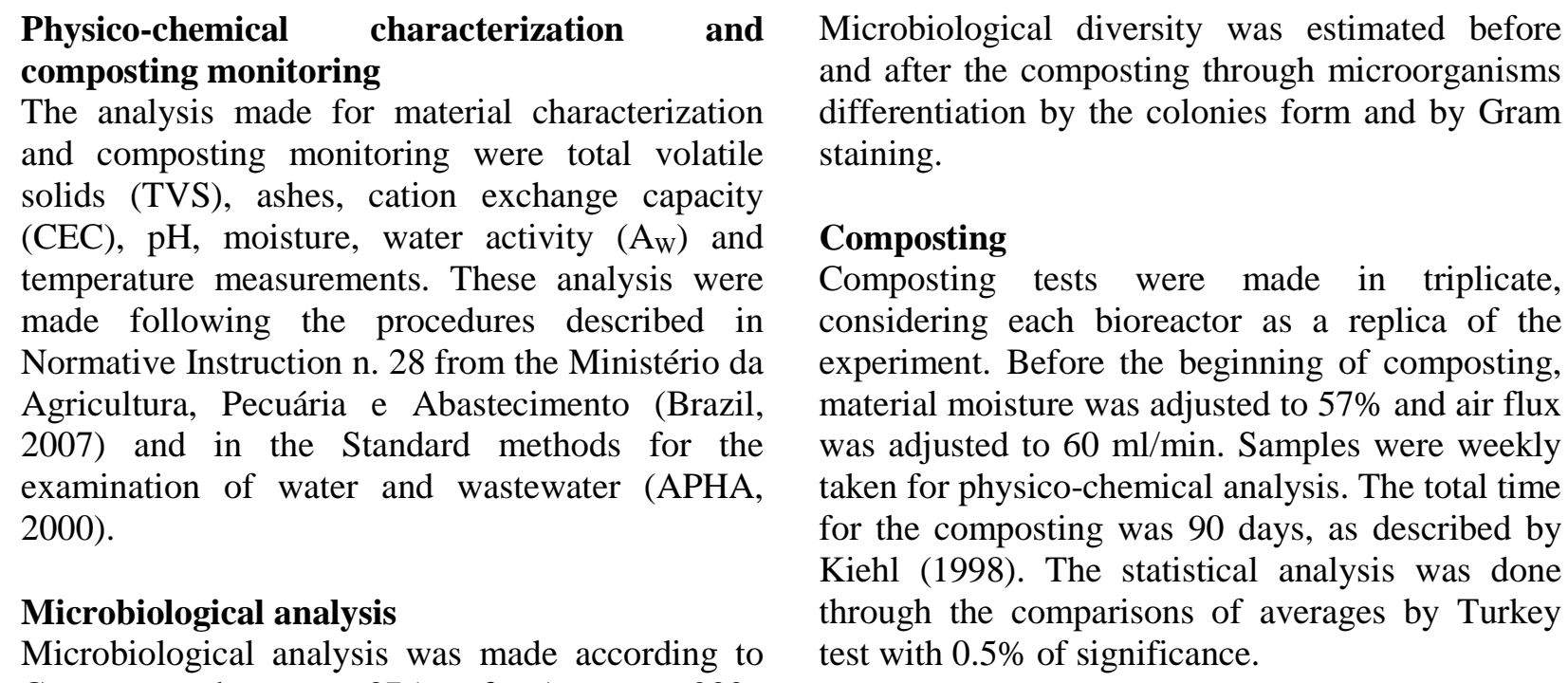




\section{RESULTS AND DISCUSSION}

According to Kiehl (1998), temperature can be an evidence of composting initiation, as it is the first parameter that changes in the system. Figure 2 showed that the thermophilic phase was reached as soon as the process began, reaching $50^{\circ} \mathrm{C}$ of maximum temperature, which lasted less than five days. According to Stentiford et al., (1992), the ideal temperature during the thermophilic phase must be between 45 and $50^{\circ} \mathrm{C}$, keeping for at least three days at $55^{\circ} \mathrm{C}$ in order to sanitize the material. Studying poultry litter carcass composting by the windrow method, Paiva (2008) achieved a sanitizing period of seven days with temperatures above $55{ }^{\circ} \mathrm{C}$. Although the thermophilic phase didn't last according to the recomendations, pathogenic organisms were not observed at the end of composting, in accordance with Conama rules n. 375 of August, 2006.

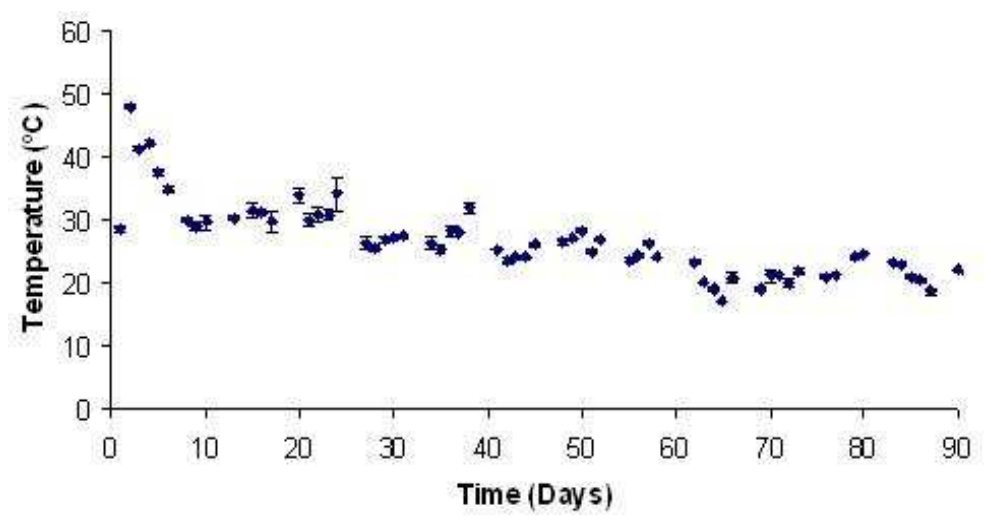

Figure 2 - Temperature variation in the composting medium as a time function.

Initially, with the start up of the process, a decrease was observed in the $\mathrm{pH}$ due to formation of some organic acids from the microbial metabolism (Valente et al., 2009). Thereafter the pH values increased (Fig. 3). Kumar et al., (2007) reported similar results during poultry litter carcass composting by the windrow method. The increase in $\mathrm{pH}$ has been attributed to the alkaline humats formation from the reaction of humic acids with alkaline chemical elements present in the composting medium (Kiehl, 2004).

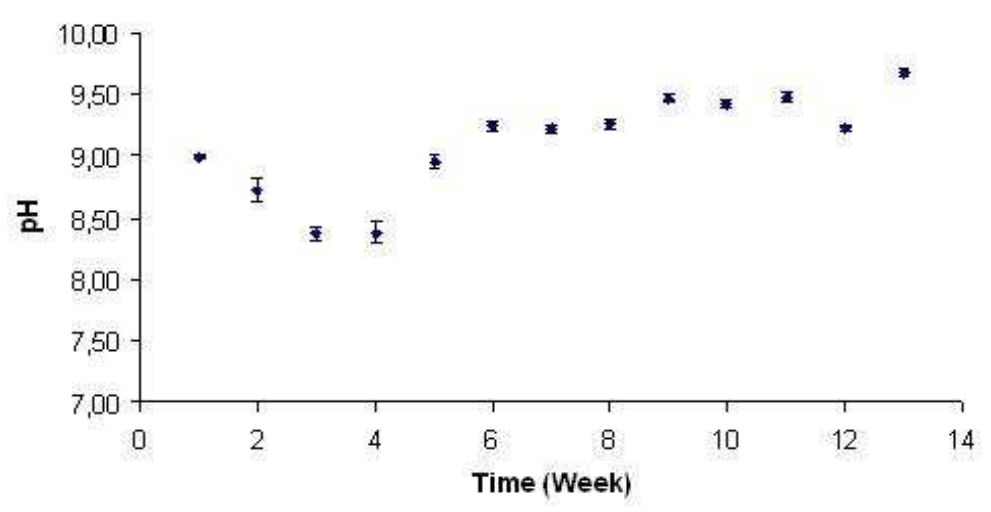

Figure 3 - $\mathrm{pH}$ variation of the medium along the time of the composting process.

Moisture is directly related to the metabolic activity of the microorganisms and consequently to organic matter decomposition. Hence, during composting, the optimum moisture content must be between 50 and 60\% (Brazil, 1999). In the present study, the moisture level was maintained close to the recommended values but showed a decrease near the end of the experiment. With the 
decrease in the moisture, there was also a decrease in the $A_{W}$ values. Water activity of a substrate is directly related to microbial metabolism. Lower $A_{W}$ values can reduce the growth of the microorganisms, hence, it is important to maintain the moisture levels enough to sustain the microbial activity (Rodríguez León et al., 2008).

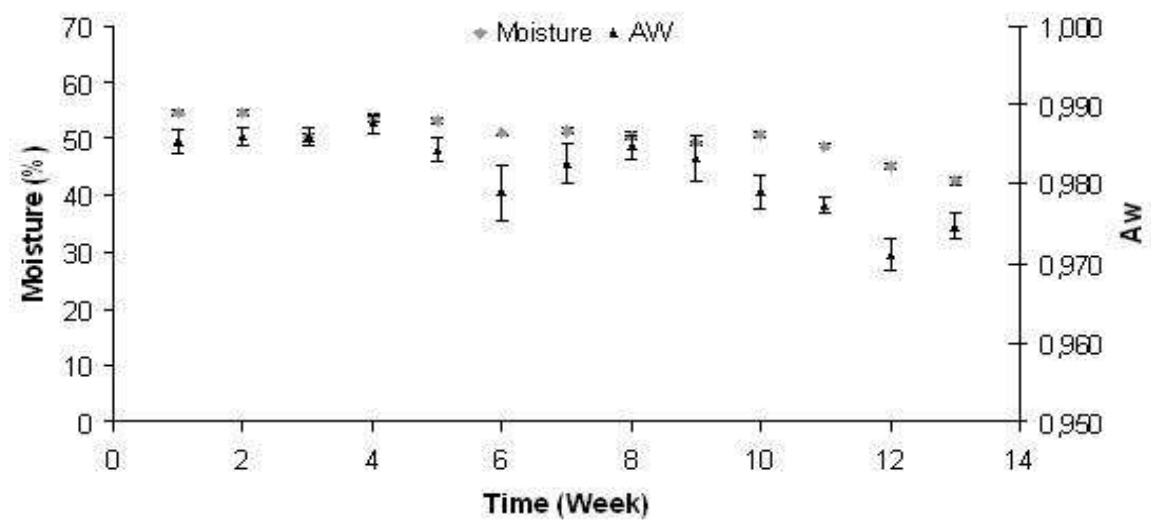

Figure 4 - Moisture and AW decrease as a time-function.

According to Roig et al., (1988), the cation exchange capacity of a soil is directly related to the functional groups of the humic substances, allowing reduction in the compost maturation degree. During compost formation there was an increase of approximately $50 \%$ of cation exchange capacity (Fig. 5). According to Pereira Neto
(2007), CEC values for an organic fertilizer must be between 1000 and $3000 \mathrm{mmol}$. $\mathrm{Kg}^{-1}$, but Kiehl (1998) found that good compost must show values between 600 and $800 \mathrm{mmol} . \mathrm{Kg}^{-1}$. Thus, even increasing the CEC, the values obtained for the compost at the end didn't achieve as reported in the literature.

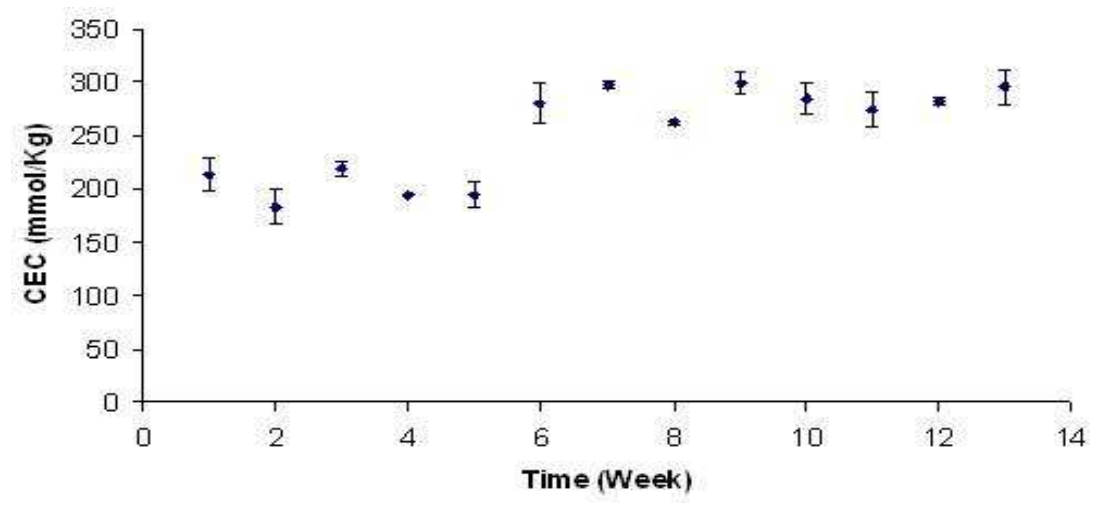

Figure 5 - Cation exchange capacity.

According to Jiménez et al., (1989), ashes and total volatile solids (TVS) of the compost are directly related to the organic matter concentration in the material. According to the results obtained in this study, there was an increase in the contents of the ashes and, consequently, a decrease in TVS values (Fig. 6). Decrease in the TVS values could be explained by the mineralization of the organic matter available for composting. Souza et al., (2002) observed similar variations for these parameters during urban organic matter composting. 


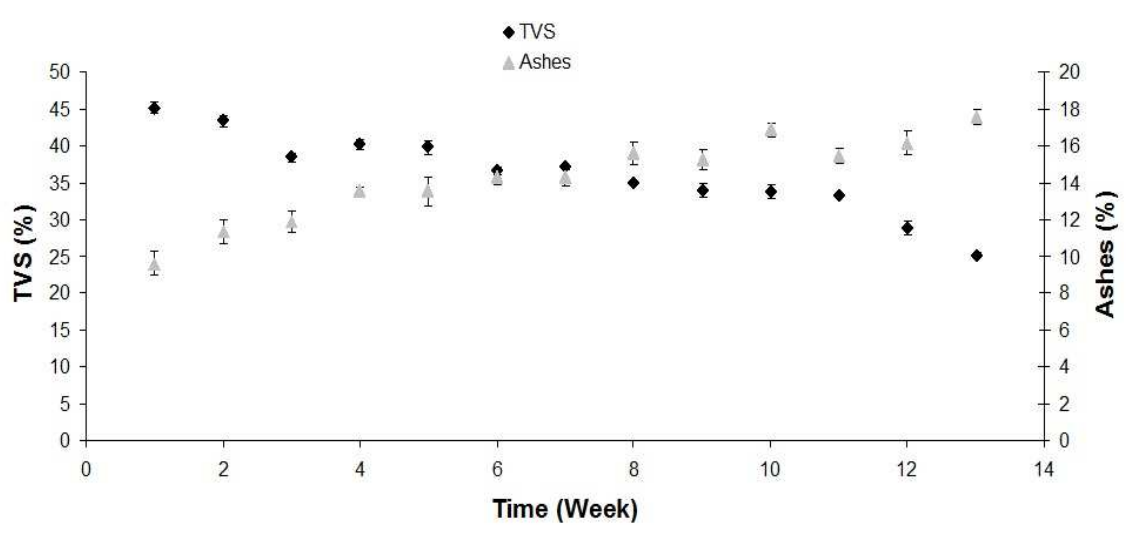

Figure 6 - Ashes and TVS values behaviors during composting.

At the end of composting, there was a decrease in the microbial diversity, as well as a changing in types of the organisms in the composting material (Fig. 7). Taiwo and Oso (2003) observed a similar behavior with the municipal solid residues composting process. According to Tiquia et al.,
(1998), the original and natural microbiota of the biomass to be composted determines the quality of material degradation. In addition, the composting process is characterized by a continuous change in the microbial species present at different time during the process (Miller, 1992).

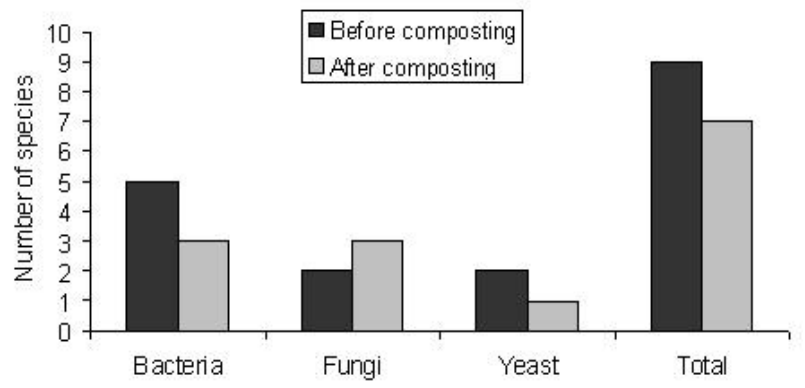

Figure 7 - Microbiological Diversity before and after the composting process.

\section{CONCLUSION}

Results showed that poultry litter could be used a substrate for composting and it did not require to carry out the composting process. The composted litter at the end of the process showed suitable physical-chemical and microbiological characteristics to be classified as a compost to be used as soil corrector and as a fertilizer. Besides, the composting process using the poultry litter would solves an environmental problem as this residue could be transformed into a useful product.

\section{ACKNOWLEDGEMENTS}

The authors wish to thank the Fundation Araucária and CAPES - Coordination of Improvement of
Higher Education Personnel for the financial support.

\section{REFERENCES}

Aires, A. M. (2009), Biodigestão anaeróbica da cama da cama de frangos de corte com ou sem separação das frações sólida e líquida. Master's thesis, Faculdade de Ciências Agrárias e Veterinárias UNESP, Jaboticabal, Brazil

APHA. AWWA. WPCF. (2000), Standart methods for the examination of water and wastewater, 20th ed, Washington

Associação Brasileira de Exportadores e Produtores de Frango de Corte. (2009), Annual report 2008/2009. São Paulo. Available at: < http://www.abef.com.br/ Relatorios_Anuais.php > Access on: June 15 ${ }^{\text {th }}, 2010$. 
Brazil. (2009), Instituto Brasileiro de Administração Municipal. Compostagem. In: Boletim técnico. São Paulo. Available at: <http://www.ibam.org.br/ publique/media/Boletim5rs.pdf.> Access on: June $20^{\text {th }}, 2010$.

Brazil. (2001), Normative Instruction n. 15, July $17^{\text {th }}$, 2001. Ministério da Agricultura, Pecuária e Abastecimento, Diário Oficial da União, Brasília, DF, July, $18^{\text {th }}, 2001$, Section 1, p. 6.

Brazil. (2007), Normative Instruction n. 28, July, 2007. Ministério da Agricultura, Pecuária e Abastecimento. Manual de Métodos Analíticos Oficiais para Fertilizantes Minerais, Orgânicos, Organominerais e Corretivos. Diário Oficial da União, Brasília, DF, July, $31^{\text {st }}$, 2007, Section 1, p.11.

Brazil. (1999), Programa de Pesquisa em Saneamento Básico. Manual prático para a compostagem de biossólidos. Rio de Janeiro. Available at: < http://www.finep.gov.br/prosab/livros/Livro\%20Com postagem.pdf> Access on: June $10^{\text {th }}, 2010$.

Brazil. (2006), Resolution n. 375 from Conselho Nacional do Meio Ambiente, August 29 2006. Ministério do Meio Ambiente. Diário Oficial da União, Brasília, DF, August 29 2006.

Fonseca, A. F.; Herpin, U.; Santos Dias, C. T.; Melfi, A. J. (2007), Nitrogen Forms, pH and Total Carbon in a Soil Incubated with Treated Sewage Effluent. Braz. Arch. Biol. Technol., 50 (5), 743 - 752

Gobbi, M. A.; Jordão Pigozzo, A. T.; Lenzi, E.; Luchese, E. B. (2000), Effects of the Application of Sewage Sludge and Fowl Manure on Soils of Paran State in Maize Plants (Zea mays L.) as a Macronutrients Source. Braz. Arch. Biol. Technol., 43 (2), 151-157

Jiménez, E. I.; Garcia. V.P. (1988). Evaluation of city refuse compost maturity: a review. Biological Wastes., 27,115-142

Kiehl, E. J. (1998), Manual de compostagem: maturação e qualidade do composto, $1^{\text {st }}$ ed. Piracicaba

Kiehl, E. J. (2002), Manual de compostagem: maturação e qualidade do composto, $3^{\text {rd }}$ ed. São Paulo

Kiehl, E. J. (2004), Manual de compostagem: maturação e qualidade do composto, $4^{\text {th }}$ ed. Piracicaba

Konzen, E. A. (2003), Fertilização de lavoura e pastagem com dejetos de suínos e cama de aves. Paper presented at $5^{\text {th }}$ Seminário técnico da cultura de milho, Videira, Santa Catarina

Kumar, V .R. S.; Sivakumar, K.; Purushothaman, M. R.; Natarajan, A.; Amanullah, M. M. (2007), Chemical changes during composting of dead birds with caged layer manure. J. Appl. Sci. Res., 10, 11001104
Matos, A. T. (2006), Tratamento e aproveitamento agrícola de resíduos sólidos. Caderno Didático $\mathrm{n}^{\circ} 37$. Departamento de Engenharia Agrícola da UFV, Viçosa, Brazil

Miller, F. C. (1993), Composting as a process based control on ecologically selective factors. In: Soil Microbial Ecology, ed. F. B. Metting. New York, pp. 515-543

Favaretto, N. Deschamps, C.; Daros, E. and Pissaia, A. (1997), Effect of Sewage Sludge on the Soil Fertility on the Growth of Plants and Productivity of Maize (Zea mays L.) Braz. Arch. Biol. Technol., 40 (4), 837 $-848$

Paiva, E. C. R. (2008), Avaliação da compostagem de carcaças de frangos pelos métodos da composteira e leiras estáticas aeradas. Master's thesis, Escola de Engenharia da Universidade Federal de Minas Gerais (UFMG), Viçosa, Brazil

Pereira Neto, J. T. (2007), Manual de compostagem, processo de baixo custo. $1^{\circ} \mathrm{ed}$. Viçosa

Rodríguez León, J. A.; Soccol, C. R.; Singhania, R. R.; Pandey, A.; Sturm, W.; Letti, L. A. J.; Vandenberghe, L. P. S.; Rodrígues Fernández, D. E. (2008), Solidstate fermentation. In Advances in Fermentation Technology, A. Pandey; C. Larroche; C. R. Soccol; C. G. Dussap. Asiatech Publishers, New Delhi, pp. 539555

Roig, A.; Lax, A.; Cegarra, J.; Costa, F.; Jernandez, M. (1988), Cátions exchanger capacity as a parameter for measuring the humification degree of manure. Soil Sci., 146, 311-316

Souza, F. C.; Neto, J. T. P.; Ceballos, B. S. O.; Mota, J. P. (2002), Avaliação da Compostagem mesofílica em escala real. Paper presented at XXVIII Congresso Interamericano de Engenharia Sanitaria e Ambiental, 27-31 Oct, Cancún, México

Stentiford, E. I. (1992), The composting process applied to sewage sludges and source separated refuse. In: Commission of the European Communites. Composting and compost quality assurance criteria. Luxembourg.

Tiquia, S. M.; Tam, N. F. Y.; Hodgkiss, I. J. (1998), Salmonella elimimination during composting of spent pig. Bioresource Technology., 63, 193-196.

Valente, B. S.; Xavier, E. G.; Morselli, T. B. G. A.; Jahnke, D. S.; Brum JR, B. S.; Cabrera, B. R.; Moraes, P. O.; Lopes, D. C. N. (2009), Fatores que afetam o desenvolvimento da compostagem de resíduos orgânicos. Arch. Zootec. 58, 59-85. 